\title{
MULHERES INVISÍVEIS EM A HORA DA ESTRELA, DE CLARICE LISPECTOR E EM DOIS IRMÃOS, DE MILTON HATOUM: MACABÉA E DOMINGAS
}

\author{
Josué Brito Santana* \\ Maria das Graças Fonseca Andrade
}

RESUMO: Este artigo pretende aproximar as personagens Macabéa, da novela $A$ bora da estrela (1977), de Clarice Lispector, e Domingas, do romance Dois irmãos (2000), de Milton Hatoum, tendo em vista a emergência da discussão sobre a invisibilidade da mulher enquanto construção social. Macabéa é mulher nordestina, pobre, feia, retirante, semianalfabeta, virgem e datilógrafa, que migra para o Rio de Janeiro e lá sofre preconceito e violência por estar fora dos atributos requeridos pela cidade grande. Domingas é mulher indígena, vítima de vários tipos de violência e ignorada em sua singularidade. Duas histórias que atravessam o tempo e o espaço e que refletem a desigualdade social brasileira e os desafios para a superação da condição de subalternidade da mulher. Alguns pensadores como: Michelle Perrot (2007), Alfredo Bosi (1981), Ecléa Bosi (2006), Antônio Cândido (2011), Stuart Mill (2006), Quijano (2005) e outros nos ajudarão a refletir sobre essas questões.

PALAVRAS-CHAVE: Mulher; Invisibilidade; Clarice Lispector; Milton Hatoum.

Um monge descabelado me disse no caminho: "Eu queria construir uma ruina. Embora eu saiba que ruína é uma desconstrução. Minha ideia era de fazer alguma coisa ao jeito de tapera. Alguma coisa que servisse para abrigar o abandono, como as taperas abrigam. Porque o abandono pode não ser apenas um homem debaixo da ponte, mas pode ser também de um gato no beco ou de uma criança presa num cubiculo. O abandono pode ser também de uma expressão que tenha entrado para o arcaico ou mesmo de uma palavra. Uma palavra que esteja sem ninguém dentro. (O olho do monge estava perto de ser um canto.) Continuou: digamos a palavra AMOR. A palavra amor está quase varia. Não tem gente dentro dela. Queria construir uma ruina para a palavra amor. Talvez, ela renascesse das ruínas, como o lírio pode nascer de um monturo". E o monge se calou descabelado. (Manoel de Barros)

Sensibilidade aguçada é o que se pode dizer dos autores quanto ao trabalho de elaboração de personagens como Macabéa, da novela ${ }^{1}$ A bora da estrela (1977), de Clarice

\footnotetext{
* Mestrando em Letras: Cultura, Educação e Linguagens pela Universidade Estadual do Sudoeste da Bahia (Uesb).

** Doutora em Literatura Brasileira pela Universidade Federal de Minas Gerais (UFMG). Professora titular da Universidade Estadual do Sudoeste da Bahia (Uesb).

${ }^{1} \mathrm{O}$ uso da nomenclatura "novela" e "romance" tem intenção meramente didática, em que aquela se refere a uma narrativa curta, maior que o conto e menor que o romance, porém esse critério é bastante simplista, pois "a busca pela definição de um gênero literário é desconcertante" (HATOUN, 2009, p. 88.)
} 
Lispector, e Domingas, do romance Dois Irmãos (2000), de Milton Hatoum, ao trazerem para a ficção a problemática da opressão, da pobreza, da violência e da invisibilidade das mulheres. Assuntos indigestos que vêm sendo debatidos, seja pelos estudos feministas com a crítica ao biologismo das ciências; seja pela Psicanálise ao tratar das considerações sobre o corpo, o uno, o desejo da mulher e a experiência desintegradora ou desenraizadora do ser; seja pelos estudos decoloniais e as epistemologias do sul ${ }^{2}$. Nesse sentido, podemos afirmar a importância da visão social nas obras literárias em questão, ao trabalharem com personagens "simples", órfãs e sobreviventes, que pelo estado de "ruína" e de "abandono" passariam desapercebidas como milhares de outras mulheres. Poder percebê-las como bem o fizeram os seus criadores é poder, de algum modo, lembrar a natureza das relações sociais e o valor dado à mulher no estabelecimento de encontros mais profundos, de afeto e de pertencimento como resultantes de uma construção ideológica.

Clarice Lispector, autora de $A$ bora da estrela (1977), tornou-se reconhecida por seu trabalho literário no qual evidencia, a um só tempo, grande capacidade introspectiva e alta elaboração estética. Escrever, para ela, era um exercício de salvação, pois:

Salva a alma presa, salva a pessoa que se sente inútil, salva o dia que se vive e que nunca se entende a menos que se escreva. Escrever é procurar entender, é procurar reproduzir o irreproduzível, é sentir até o último fim o sentimento que permaneceria apenas vago e sufocador. Escrever é também abençoar uma vida que não foi abençoada. (LISPECTOR, 2004, p. 179)

A hora da estrela conta a história de Macabéa, debruçando-se sobre a temática da fome, da exclusão e da invisibilidade da mulher, emigrante nordestina e problematiza as mazelas da nossa sociedade, independentemente das propagandas de progresso e de prosperidade da nação, tão comuns à época, especialmente na cidade do Rio de Janeiro. Mas, antes do espetáculo da miséria de Macabéa, o livro é também uma homenagem a outras

\footnotetext{
${ }^{2}$ Trata-se de uma metáfora proposta por Boaventura de Souza Santos (2009) em oposição ao pensamento moderno do Norte global, o qual separou o conhecimento entre certo e errado, verdadeiro e falso, que ignora a história, a cultura e a diversidade de saberes do mundo, especialmente da América Latina e da África. Foge aos objetivos deste artigo realizar uma análise detalhada dessas fontes. Contudo, não poderia deixar de mencioná-las por representarem um avanço nas problematizações sobre a alteridade e o lugar da mulher na sociedade.
} 
formas de expressão artística como a música, o cinema e a fotografia. Logo no início do texto, lemos: "DEDICATÓRIA DO AUTOR” e entre parênteses o destaque: “(Na verdade Clarice Lispector)", revelando o gosto musical da escritora, que anuncia os compositores Schumann, Chopin, Stravinsky, Richard Strauss, Debussy e outros “que em mim atingiram zonas assustadoramente inesperadas, todos esses profetas do presente e que a mim me vaticinaram a mim mesmo a ponto de eu neste instante explodir em: eu. (LISPECTOR, 1998, p. 9, grifo nosso) ${ }^{3}$. A presença da música é pano de fundo que favorece a aproximação do leitor à figura singela de Macabéa, como veremos mais tarde na cena em que ela se refere à música Una Furtiva Lacrima (HE, p. 51), contraponto para se pensar na armadilha de pensar que a fruição da obra de arte tem relação com o requinte de determinados grupos sociais. Com relação às obras literárias, o texto cita também os clássicos: Alice no País das Maravilhas, de Lewis Carroll (HE, p. 50) e Humilhados e Ofendidos, de Fiódor Dostoiévski (HE, p. 40), mas não serão objeto da análise desse artigo.

Quanto à inspiração para a construção da personagem Macabéa, Clarice Lispector revela que foi fruto das suas experiências e observações ao perambular pela cidade:

Em Recife onde morei até doze anos de idade, havia muitas vezes nas ruas um aglomerado de pessoas diante das quais alguém discursava ardorosamente sobre a tragédia social. E lembro-me de como eu vibrava e de como eu me prometia que um dia esta seria a minha tarefa: a de defender os direitos dos outros. No entanto o que terminei sendo, e tão cedo? Terminei sendo uma pessoa que procura o que profundamente se sente e usa a palavra que o exprima. É pouco, muito pouco. (LISPECTOR, 1999, p. 150)

Em Clarice Lispector, essa desconhecida, Júlio Lerner (2007, p. 26), traz a seguinte confissão da escritora:

- Eu morei em Recife, eu morei no Nordeste, me criei no Nordeste. E, depois, no Rio de Janeiro tem a feira dos nordestinos no Campo de São Cristóvão e uma vez eu fui lá... E peguei o ar meio perdido do nordestino no Rio de Janeiro... Daí começou a ideia de um... Depois eu fui a uma cartomante e imaginei... Ela disse várias coisas boas que

${ }^{3}$ A partir desse momento, as referências relativas ao livro $A$ hora da estrela terão a abreviação HE, seguida de indicação de página. 
iam acontecer e imaginei, quando tomei o táxi de volta, que seria muito engraçado se um táxi me atropelasse e eu morresse depois de ter ouvido todas essas coisas boas... Então daí foi nascendo também a trama da história.

Milton Hatoum, autor do romance Dois Irmãos (2000), nasceu em Manaus no dia 19 de agosto de 1952, é escritor, tradutor e ensaísta. Atualmente, escreve a trilogia O Lugar Mais Sombrio. Estreou em 1989 com o romance Relato de um Certo Oriente e, após onze anos, publicou Dois irmãos, livros muito premiados. A trama dos romances tem a peculiaridade de apresentar personagens complexas, imersas no cotidiano comum de Manaus, permitindo a reflexão sobre os problemas sociais do seu tempo. Com relação aos precursores de Dois Irmãos, é possível perceber intenso trabalho de leitura e de pesquisa noutras fontes, sendo impossível esgotá-las. Percebemos diálogo com a mitologia ameríndia, com a narrativa bíblica do livro de Gêneses, com o mito grego Édipo Rei, com o romance Esaú e Jacó, de Machado de Assis, e influência de autores como Flaubert, Balzac, Guy de Maupassant, Joseph Conrad, Jorge Luis Borges, para citar alguns. O que nos permite entender que:

Todo texto, portanto, constitui-se como um jogo de forças, em que a subjetividade daquele que produz o discurso está entremeada pelo seu contexto histórico, bem como por todas as interferências de sua cultura e de suas leituras. Assim, a intertextualidade é a maneira real da construção do texto. (MELLO, 2014, p. 40)

Para compor Domingas, personagem que nos interessa neste momento, Milton Hatoum se inspirou, essencialmente, no conto de Flaubert "Um coração simples". Essa experiência vai ser lembrada pelo texto "Flaubert, Manaus e madame Liberalina" (2009), no qual Milton Hatoum descreve a sua sorte de, ainda menino, poder ouvir esse autor através dessa senhora, num ambiente de proteção e cuidado, o que lhe marca profundamente:

Enquanto a chuva caía com a intensidade de um dilúvio, ouvia a voz de Madame traduzir o conto Un coeur simple, de Flaubert. De simples, esse texto não tinha nada. Não existe coração simples na vida nem na literatura. Mas a ironia, que nem sempre faz parte da vida, já estava no título do relato do Urso de Croisset. "Estás vendo como o autor se esconde na história? Podes perceber que ele não aparece?" Não vi, nem percebi: não fui esse gênio que leu Proust antes do 
primeiro beijo. O que eu percebi - ou intuí - é que a história de Félicité não era apenas uma história francesa [...]

Na tradução feita e lida lentamente por Madame Libê, era impossível ser indiferente ao sofrimento da pobre empregada invejada por outras patroas de Pont l'Evêque. Sofrimento de uma vida obediente, que fracassou no amor; ou melhor, foi ludibriada no amor e nos laços de família, e explorada até a morte nas relações de trabalho. Isso eu não apenas percebi como também tracei algum paralelo com a vida das empregadas que conheci e com as quais convivi em Manaus. Jovens ou velhas, elas se extenuavam para comer e ter um teto nos fundos da casa. Às vezes nem se tratava de uma casa grande, pois essas empregadas não remuneradas podiam morar em uma edícula de casas da classe média. Nesse aspecto, lembravam as Félicités da França do século XIX. Além disso, as personagens provincianas do conto, excetuando os nobres decadentes e patéticos de Pontl'Évêque, mantinham alguma afinidade com pessoas que conheci ou que se exibiam no imenso palco da província. Uma certa vulgaridade e uma bêtise desenfreada os unia. As distâncias - geográfica, temporal, cultural e social - não aboliam totalmente certos paralelismos, afinidades e confluências entre o ambiente da narrativa e o tempo presente, da leitura. (HATOUM, 2009, p. 87)

A potência do texto o faz pensar nas questões do seu tempo, o abismo em que separa ricos e pobres, a violência, a invisibilidade das mulheres e a prática da exploração. Daí a importância de se perceber Domingas muito além de uma personagem secundária, mas uma personagem importante à nossa cultura, na qual se escancaram as diferenças:

Ou seja, as diferenças entre as duas sociedades reforçavam o que nelas havia em comum: um fosso social entre a elite e as pessoas humildes. E o mais importante: o mundo do trabalho e das relações sociais envolve a personagem numa rede cada vez mais constrita e cruel cujo limite é a loucura, o delírio e, por fim, a morte. Pela primeira vez ouvi falar da revolução de 1848, da Comuna de Paris e da guerra franco-prussiana. Alguns desses eventos históricos são mencionados no conto, e o que deveria ter sido apenas uma série de aulas de língua foi, na verdade, uma lição sobre a cultura francesa [...]

Não sei até que ponto esse e outros textos abalaram minha vida. As paixões e as tragédias nos abalam mais do que as palavras, pois a vida é mais complexa e surpreendente do que a literatura. Mas, como acontece com os grandes textos literários, a cada releitura de Um coração simples encontrava na vida das personagens uma elaboração complexa das relações humanas. $\mathrm{Na}$ linguagem precisa e exata de Flaubert, a trajetória de Félicité se comprime em menos de cinquenta páginas. Um conto que não se estrutura como um conto. Tampouco como uma novela, muito menos como um romance. 
Nesse sentido, a busca pela definição de um gênero literário é desconcertante. (HATOUM, 2009, p. 88)

Numa entrevista dada à revista Navegações (2009, p. 160), Milton Hatoum responde à pergunta sobre o caráter de ficção e de realidade das personagens do romance Dois Irmãos, da seguinte maneira:

Alguns traços de certas personagens foram inspirados na minha família ou em pessoas que conheci, mas felizmente nenhum parente se reconheceu nos romances. Penso que a personagem mais próxima da minha vida é o Halim, do Dois irmãos. Pensei no meu pai quando esbocei essa personagem. Ou melhor, na memória que tinha do meu pai, que acabara de morrer quando comecei a escrever esse romance. De um modo geral, as personagens são ou deveriam ser bem mais complexas que as pessoas com as quais convivemos. Mas é quase certo que muitas personagens devem ter alguma coisa de mim.

A novela A Hora da Estrela apresenta o narrador, Rodrigo S. M., como um dos personagens principais, pelo menos é o que ele afirma. Trata-se de um escritor angustiado, por não saber como escrever a realidade de uma mulher, feia, magra, retirante nordestina, semianalfabeta, virgem e péssima datilógrafa, que atende pelo nome Macabéa. A primeira parte do texto é uma longa justificativa para a sua aflição, um choque de distanciamento entre a sua vida e a de Macabéa. Por isso, o narrador passa a viver o pesadelo daquela moça, a senti-la de fato, pois "Até a dor de dentes que perpassa essa história deu uma fisgada funda em plena boca nossa.” (HE, p. 11). Inevitavelmente, o narrador se questiona sobre o modo de escrita para se convencer de que aquela realidade só poderia aparecer no texto de forma simples "[...] para captar a sua delicadeza, a vaga existência.” (HE, p. 15), o que representa um instante de emergência e de grande assombro para ele. Macabéa é o caos, a prova de que há algo de muito errado no mundo e que é preciso agir. Para isto:

[...] terá de abrir um caminho através do caos dessas reações para desembocar em sua autêntica postura de valores e para que o rosto da personagem se estabilize, por fim, em um todo necessário. Quantos véus, que escondem a face do ser mais próximo, que parecia perfeitamente familiar, não precisamos, do mesmo modo, levantar véus depositados nele pelas casualidades de nossas reações, de nosso relacionamento com ele e pelas situações da vida, para ver-lhe o rosto em sua verdade e seu todo. $\mathrm{O}$ artista que luta por uma imagem 
determinada e estável de um herói luta, em larga medida, consigo mesmo. (BAKHTIN, 1997, p. 26-27)

O narrador também justifica o motivo de ser ele, um homem, a pessoa indicada para contar a história "porque uma escritora mulher pode lacrimejar piegas." (HE, p. 14), talvez por deduzir a existência de uma escrita de homem diferente de uma escrita de mulher, que é mais "lacrimosa", enquanto a do narrador parece ser "fria". Ou quem sabe uma máscara da autora para criticar o paradigma dominante? Afinal: escrita tem gênero? Quais assuntos interessam à escrita de uma mulher? Vale destacar o trabalho de Lúcia Castelo Branco sobre escrita feminina (1991), outro modo de escrever para além dos sexos, que “[...] não busca o preenchimento (o Grande Sentido...), a certeza, a resolução do conflito, a comunicação da mensagem, mas a carícia que o som, o ritmo, a modulação da voz e a respiração possam produzir na orelha do leitor. [...]". Nesse aspecto, ainda que o narrador de A Hora da Estrela chame a atenção para o seu modo de escrever, próprio de homem, o texto permanece eivado de silêncios, de engasgos e de ausências de respostas.

Ao escrever sobre Macabéa, o narrador aproveita para contar a própria história, a sua vida intangível e sem sentido "A minha vida a mais verdadeira é irreconhecível, extremamente interior e não tem uma só palavra que a signifique [...]” (HE, p. 11), e afirmar que essa ausência de significado o aproxima da personagem Macabéa pela incapacidade de ambos de fazerem falta (HE, p. 14). Logo, a regurgitação em torno de si como um recurso de aproximação de histórias, num processo de empatia pelo desespero. Andrade (2011) em "Mulher é desdobrável: autores e personagens em A hora da Estrela e Um sopro de vida, de Clarice Lispector", vale-se do conceito francês de mise en abyme, proposto por André Gide e que significa "cair no abismo":

[...] para falar sobre narrativas que contêm dentro de si próprias outras narrativas. Pode ser verificado também na pintura e no cinema. $\mathrm{Na}$ literatura, um exemplo clássico é As mil e uma noites. Vale lembrar que, segundo a própria escritora, desde antes da escrita ela já praticava com outra criança uma espécie de história sem fim, que ia sendo construída a duas vozes e que, diante de um impasse (o que provocaria o fim da narrativa), uma delas retomava a história e a ela dava sequência. (ANDRADE, 2011, p. 1729-1740) 
Um abismo que quase engole o narrador, sufocando-o diante da impossibilidade da escrita: "Este livro é um silêncio. Este livro é uma pergunta" (HE, p. 17). Mas qual? Sugere e não responde. Na condição de leitor, arriscamos imaginar que, talvez, pudesse ser esta: qual é a medida suportável de invisibilidade para a mulher? Entretanto, mesmo diante do absurdo da vida de Macabéa, o narrador vai colocar a ideia para fora, pois se "há direito ao grito. Então eu grito" (HE, p. 13). Enxergando na personagem a oportunidade de se questionar sobre a ausência de um "delicado essencial" (HE, p. 12, grifo nosso) no mundo. Afinal, é impossível ser indiferente já que Macabéa insiste em existir numa cidade "toda feita contra ela" (HE, p. 15), assim como "[...] milhares espalhadas por cortiços, vagas de cama num quarto, atrás de balcões trabalhando até a estafa" (HE, p. 14). O narrador reconhece, entretanto, que essa multidão continua invisível para muitos que estão "fingindo de sonsos" (HE, p. 12). E reconhece que é preciso transgredir: "Transgredir, porém, os meus próprios limites me fascinou de repente. E foi quando pensei em escrever sobre a realidade, já que essa me ultrapassa” (HE, p. 17). Uma experiência autêntica de ver e de trabalhar que, segundo Bosi (2006, p. 24) é capaz de "devassar as formas ocultas de opressão." Eis a importância desse texto. Aliás, uma literatura conformada com a realidade e ajustada aos interesses de classe é passatempo e conveniência. Macabéa é um grito por socorro da mulher subalternizada, uma tese sobre as consequências da invisibilidade e a infâmia da pobreza que "é feia e promíscua" (HE, p. 22).

Por sua vez, o narrador do romance Dois Irmãos (2000) é um escritor que se esconde nas brechas, que escuta por trás das paredes e busca compor a sua origem através de fragmentos de histórias, de silêncios e de lembranças contadas pelos patrões e por sua mãe. É filho bastardo da índia Domingas, empregada doméstica da casa. Aos poucos, ele monta um quebra-cabeças e desvenda o segredo da sua paternidade. A narrativa está ambientada na região norte do Brasil, na cidade de Manaus, com o tempo indo e vindo, entre o início do século XX até a década de 60 . O texto traz o recorte histórico marcado pelas consequências do ciclo da borracha, entre a euforia e a decadência, passando pela II Guerra e a Ditadura Militar. Ao elaborar o plano de descoberta da própria origem, o narrador conta com um interlocutor e confidente, Halim, marido de Zana e patrão de Domingas, que "Assim viveu, 
assim o encontrei tantas vezes, pitando o bico do narguilé, pronto para revelar passagens de sua vida que nunca contaria aos filhos. (HATOUM, 2000, p. 52) ${ }^{4}$ Assim, tanto Halim quanto Nael divagam em suas lembranças, as do ancião sobre um passado ordenado e feliz, diferente das de Nael que se baseavam no caos e nas incertezas. Entretanto, tal exercício de memória, através do mergulho nas lembranças, configura-se como uma reinvenção do passado, uma forma de criação do presente e do futuro, já que é impossível se ter acesso ao passado sem transformá-lo:

A memória não é sonho, é trabalho. Se assim é, deve-se duvidar da sobrevivência do passado, "tal como foi", e que se daria no inconsciente de cada sujeito. A lembrança é uma imagem construída pelos materiais que estão, agora, à nossa disposição, no conjunto de representações que povoam a nossa consciência atual. Por mais nítida que pareça uma lembrança de um fato antigo, ela não é a mesma imagem que experimentamos na nossa infância, porque nós não somos os mesmos de então e porque nossa percepção alterou-se e, com ela, nossas ideias, nossos juízos de realidade e de valor. O simples fato de lembrar o passado, no presente, exclui as identidades entre as imagens de um e de outro, e propõe a sua diferença em termos de ponto de vista. (BOSI, 2006, p. 55, grifo do autor.)

Em busca de sentido, Domingas, invisível enquanto mulher, assume um papel fundamental na análise do narrador. Tudo em sua mãe tem importância, especialmente o silêncio que esconde um segredo. Cândido (2011, p. 178) afirma que "toda obra literária pressupõe esta superação do caos, determinada por um arranjo especial das palavras e fazendo uma proposta de sentido”. É graças a essa experiência caótica do não-pertencimento que personagens e narrador vagueiam pela cidade.

Em A Hora da estrela, Macabéa migra, aos dezenove anos, para o Rio de Janeiro, nos anos 70, por necessidade de sobrevivência. Nasceu no sertão de Alagoas, raquítica e mirrada. Aos dois anos de idade perdeu os pais, indo morar com a tia, que lhe batia muito, tendo, por isso, adquirido o hábito de andar de cabeça baixa. Não teve direito sequer a um cachorrinho de estimação na infância e achava que não merecia nem o amor de um bicho

${ }^{4}$ A partir desse momento, as referências sobre o romance Dois Irmãos trarão a abreviação DI, seguida de indicação de página. 
(HE, p. 29). O que lhe doía mais do que as surras da tia era a privação da única paixão de sua vida: "goiabada com queijo" (HE, p. 28). Com a morte da tia, Macabéa fica sozinha no mundo e decide ir para o Rio de Janeiro. Macabéa aparece como um ser desapegado das suas origens e uma dor constante vai acompanhar a trajetória dessa moça (HE, p. 62), uma dor de não pertencer, de não fazer falta para ninguém Diferentemente do seu narrador, não tem sobrenome, nem lembranças dos pais, nem dos amigos, nem da infância. Macabéa torna-se secretária num escritório e sente orgulho da "profissão", talvez por achá-la um pouco superior à de uma empregada doméstica ou faxineira, como a maioria das migrantes nordestinas. Esta condição também lhe poupava da prostituição, de não ter que vender o corpo por um prato de comida (HE, p. 13). Mas a condição de semianalfabeta não lhe permitia estabilidade no emprego, por isso vivia sob constante ameaça de demissão, pois era uma péssima datilógrafa.

Domingas, do romance Dois Irmãos, é levada para Manaus para viver como escrava, primeiro num orfanato e depois na casa dos imigrantes libaneses, Halim e Zana. Teve uma origem cercada por cuidados e uma relação comunitária de afeto em sua aldeia, mas ao ficar órfã, deixa a sua terra, desatrelando-se da família. Segundo Perrot (2007, p. 17) "Os homens são indivíduos, pessoas, trazem sobrenomes que são transmitidos. Alguns são 'grandes', 'grandes homens'. As mulheres não têm sobrenome, têm apenas um nome. Aparecem sem nitidez, na penumbra dos grupos obscuros". Detalhe curioso é que o prenome Macabéa lembra o nome de um líder do povo hebreu que lutou contra o jugo dos gregos (MEDEIROS, 2017, p. 151-152). Já o nome Domingas vem do latim Dominicius e significa, literalmente, conforme o Dicionário Houaiss de Português (2001), propriedade do Senhor. Apesar da mudança do orfanato para a cidade, permaneceu a condição servil de Domingas a destoar dos apelos do progresso da cidade de Manaus.

Resguardadas as distâncias temporais e geográficas, a Manaus dos anos 20 aos 60 do século passado, descrita no romance Dois Irmãos, não difere muito da realidade do Rio de Janeiro de Macabéa, dos anos 70, especialmente quanto à pobreza e à precariedade decorrentes do aumento desordenado da população, incluindo o aumento dos migrantes nordestinos em busca de sobrevivência. No texto Urbanismo na periferia do mundo globalizado: 
metrópoles brasileiras Maricato (2000) aponta que a "tragédia" das grandes cidades brasileiras não é fato decorrente de "décadas perdidas", pois sempre se deu através da exclusão social, fundamentada no processo de colonização e de escravização, em que o homem se torna mercadoria, em que as forças produtivas são reguladas pelo capital, em que as pessoas são atraídas pelas propagandas de "progresso" e pela necessidade de inclusão. Holanda (2002, p. 31) também chamou a atenção para o nosso passado sombrio considerando-o como "o fato dominante e mais rico em consequências", o que nos ajuda a entender melhor os mecanismos de construção de discursos e a produção de modos de existir, subjugados, especialmente da mulher pobre, quer seja nordestina ou indígena. No livro Minha História das Mulheres, Michelle Perrot (2007, p. 11) faz a seguinte observação:

Minha história das mulheres faz valer o dito de que toda história é história contemporânea: tem um compromisso com o presente, ou seja, interroga o passado tomando como referência questões que fazem parte de nossa vida, como a existência de desigualdades de gênero, os significados das aparências, as manifestações da sexualidade, a luta por direitos, o papel da família, do Estado e das religiões no cotidiano das pessoas, as dificuldades e possibilidades de acesso à cultura, entre outras.

O Rio de Janeiro era um lugar estranho para Macabéa e ela precisaria de amigos para deambular. Para escapar da solidão, Macabéa se refugiava nas programações da sua Rádio Relógio. A voz do locutor da Rádio e as propagandas alimentam seus sonhos, seus desejos de interlocução. O seu desejo de se sentir amada era tanto que chega a demandar de Olímpico, seu "namorado" que ele lhe fizesse ao menos uma ligação telefônica, já que “[...] nunca recebera uma carta em sua vida." (HE, p. 47) Apesar da voz fraca e dos assuntos resumidos, Macabéa tinha desejo de diálogo e procurava se exprimir ainda que fosse num esforço inútil com “o seu diálogo [...] sempre oco” (HE, p. 54). Macabéa também gostava da própria companhia e da solidão, já que não era compreendida, tanto é verdade que simulou dor de dente para poder ficar sozinha e ter "um quarto só para ela" (HE, p. 41). Gostava de ouvir música. Aliás, a música é parte integrante também da vida da escritora, 
que insiste em destacá-la desde o início da novela. Macabéa ouve a música Una Furtiva Lacrima, interpretada por Enrico Caruso, tenor italiano, e em seguida o narrador explica:

Era a primeira vez que chorava, não sabia que tinha tanta água nos olhos. Chorava, assoava o nariz sem saber mais por que chorava. Não chorava por causa da vida que levava: porque, não tendo conhecido outros modos de viver, aceitara que com ela era "assim". Mas também creio que chorava porque, através da música, adivinhava talvez que havia outros modos de sentir, havia existências mais delicadas e até com um certo luxo de alma. (HE, p. 51)

A música "Una furtiva lacrima" se refere à ópera italiana "L'Elisir d'amore", de Gaetano Donizetti - 1832 e conta a história de um camponês ingênuo de nome Nemorino apaixonado pela rica Adina. Esta casa-se com outro. Porém, Nemorino é persistente e acredita nos poderes milagrosos de um elixir. Mas é a herança de um tio que faz a sua vida mudar. Adina se convence diante dos esforços do camponês e declara o seu amor por ele. A semelhança da história da personagem Nemorino com a vida de Macabéa não se dá por acaso. Entre eles há semelhanças quanto à ingenuidade e à fé cega na bondade das pessoas. Mas, se Nemorino, ainda que enganado pelo charlatão do elixir, chega a conseguir os seus objetivos, Macabéa, ao contrário, sofrerá as consequências de sua ingenuidade. Macabéa desconhece a história da ópera, mas inundada pela potência da música vê-se suspensa, momentaneamente, da realidade que lhe atravessa e a transcende. O que nos permite considerar que a música, por seu caráter universal, não se prende ao gosto de determinadas classes sociais.

Domingas se dedicava ao trabalho em tempo integral desde a época do orfanato até depois, quando foi entregue como "escrava" da família. Durante as noites, quando deveria descansar, costumava socorrer o filho caçula da patroa, quando chegava bêbado de suas noitadas ou então podia ser vista pelo vão da janela a cantar para tentar afastar a insônia. Quanto a passeios pela cidade, o narrador se recorda de uma única vez em que sua mãe "quis sair da rotina", quando puderam fazer uma viagem até a aldeia onde Domingas 
nascera. "Ainda estava escuro quando ela chacoalhou minha rede; já tinha preparado o café da manhã e cantava baixinho uma canção. Não queria acordar os outros, estava ansiosa para partir." (DI, p. 74, grifo nosso). Nessa viagem, ela se alegra, "quase infantil, dona de sua voz e do seu corpo.” (DI, p. 74). Domingas conta um pouco da sua história para o filho, fala sobre a aprendizagem dos passarinhos e como aprendeu com as mulheres da vila a arte do preparo de comidas. Conta a morte do pai e quando foi, contra a própria vontade, para orfanato. Fala da faina de escrava e das noites de tristeza naquele lugar, e que “[...] fechava os olhos e fingia dormir, e se lembrava do pai e do irmão. Chorava quando se lembrava do pai, dos bichinhos de madeira que fazia para ela, das cantigas que cantava para os filhos.” (DI, p. 76). O narrador se surpreende de como a sua mãe se tornara falante, mas no retorno à casa dos patrões ela volta para o seu mundo de silêncio e solidão. Daí, entendemos que as noites de Domingas eram momentos de tristeza e de lembranças, daí as canções em balbucio, provavelmente aquelas que o seu pai cantava. No início, Domingas resistiu como pôde à dominação do trabalho, mas desistiu da liberdade quando a patroa ficou grávida dos gêmeos, Yaqub e Omar. Zana dedicava ao caçula, Omar, um amor exagerado, beirando incesto, com a desculpa de que foi uma criança frágil, enquanto o primogênito ficava aos cuidados da "cunhatã mirrada, meio escrava, meio ama..." (DI, p. 67). Domingas "brincava com ele, diminuída, regredindo à infância que passara à margem de um rio, longe de Manaus.” (DI, p. 68) e passeavam pela cidade, o que provocava maledicências das pessoas que diziam: "Essas cunhatãs malinavam as crianças [...]" (DI, p.68). Por isso, Domingas “preferiu capitular, deixou de agir, foi tomada pela inação.” (DI, p. 67). O caçula, Omar, reivindicava todos os afetos das mulheres da casa para si e estupra Domingas, num acesso de ciúmes:

Desde o tempo em que brincavam, passeavam. Omar ficava enciumado quando via os dois juntos, no quarto, logo que o irmão voltou do Líbano. Com o Omar eu não queria... Uma noite ele entrou no meu quarto, fazendo aquela algazarra, bêbado, abrutalhado... ele me agarrou com força de homem. Nunca me pediu perdão. (DI, p. 241)

Apesar da violência da cena, não podemos ser precisos e dizer que Omar é o pai do narrador, já que há indícios de que Domingas tenha se relacionado sexualmente com os 
demais homens da casa. No romance aparecem, inclusive, difamações sobre o envolvimento de Halim com as índias e a existência de curumins (crianças), embora ele negue, não deixa de ser um importante indício das relações promíscuas entre patrões e empregados, gravidezes indesejadas, muitas vezes, justificadas por lendas como as do boto no imaginário local (DI, p. 162), e ainda a descrição do ambiente da casa dos patrões, repleto de sensualidade, afagos excessivos e de possibilidades para o sexo (DI, p. 65). A intriga está ligada às preferências da mãe pelo filho caçula e do amor dos gêmeos pela mesma garota. Domingas é absorvida por Yaqub “[...] se deixara encantar por aquele olhar [...]” (DI, p. 30) e quando flagra Yaqub namorando a sua Lívia, nos fundos da casa, sente ciúmes e vontade de estar no lugar daquela menina. (DI, p. 44). Durante a partida de Yaqub para São Paulo, Domingas denuncia o seu sentimento ao perguntar "Vais levar aquela moça contigo?" (DI, p. 112). Com o casamento de Yaqub com Lívia, Domingas esmorece, um cansaço a vence e o tempo corrói as suas esperanças. Resta ao narrador, descrever o estágio em que se arrasta a sua mãe: "Nossas conversas rarearam, e, quando ela folgava, sentava no chão ou deitava na rede, inerte" (DI, p. 240-241).

Macabéa vê um homem, o paraibano Olímpico de Jesus, jovem metalúrgico e sonhador, de sobrenome Moreira Chaves, acrescentado por conta própria, para esconder a ausência paterna (HE, p. 44). O nome Olímpico lembra o lugar dos deuses gregos, referência à dominação, poder e glória. No entanto, a ausência paterna e a pobreza o nivelam à condição análoga à dos demais nordestinos, subjugados nas grandes capitais. $\mathrm{O}$ que $\mathrm{o}$ diferenciava era a ambição e o desejo de um futuro glorioso. Olímpico e Macabéa iniciam um namoro esquisito e insosso. Enquanto ela tentava emendar um diálogo com base nas informações da Rádio Relógio, Olímpico se enrolava em ignorância e insensibilidade, ainda que se julgasse inteligente. As poucas conversas resultavam em "farinha, carne de sol, carne-seca, rapadura, melado" (HE, p. 47), a realidade imediata da fome. Mas a moça queria mais e preparava ensaios românticos, começava a falar de assuntos a esmo, a interrogar os sentidos das palavras como "efeméride", começava a ter "alegria de viver" (HE, p. 51), achava que era notada, chegando a sonhar até mesmo com a possibilidade de casamento, de pertencer e de ser amada, ainda que o seu "namorado" não fosse capaz de compreendê- 
la. Ela queria qualquer assunto para fazer durar o seu novo estado de felicidade repentina (HE, p. 53). A questão é que Macabéa não havia notado um pormenor das relações sociais: o jogo das aparências. No espelho, o seu reflexo a mostrava "toda encardida, pois raramente se lavava" (HE, p. 27) e ignorava a "união ostensiva do sujeito com a Aparência dominante.” (SCHWARZ, 1988, p. 10). Entretanto, se as suas condições sociais de existência lhe impediam de ter acesso ao mais básico, como a comida e a moradia, como se preocupar com aparência? Diante disso, o narrador descreve a pobreza como sendo "feia e promíscua" (HE, p. 22). Antes, o olhar que Macabéa tinha de si era um olhar de reprovação e, sendo assim, tornava-se invisível e imprópria a uma mirada, condição que lhe impedia de ser por faltar "olhos para mirá-la e admirá-la. O olhar dos outros: primeiro espelho." (BOSI,1981, p. 20). Com o tempo, com a prosperidade do seu namoro, inevitavelmente a felicidade lhe traria uma preocupação com o autocuidado. O fato é que, ao ver Glória, a colega de trabalho de Macabéa, Olímpico desiste do namoro, pois havia "dentro de si a dura semente do mal" (HE, p. 47). Glória era mulher negra, que pintava o cabelo crespo de louro para esconder a sua "mulatice" (HE, p. 59). Era uma mulher capaz de provocar o desejo e as fantasias masculinas. Era "material de boa qualidade" e tinha, mãe, pai e comida quente (HE, p. 59). Tinha ancas avantajadas e "pelos quadris adivinhava-se que seria uma boa parideira" (HE, p. 60). Detalhe que demonstra a nossa herança colonial e a dificuldade em separar a mulher do sexo e dos instintos animais. "Glória roliça, branca e morna. Tinha um cheiro esquisito. Porque não se lavava muito, com certeza. Oxigenava os pelos das pernas cabeludas e das axilas que não raspava. Olímpico: será que ela é loura embaixo também?” (HE, p. 63-64). A desculpa encontrada por Olímpico para definir tamanha canalhice foi a de que Macabéa era "um cabelo na sopa, que não dá vontade de comer" (HE, p. 60). Glória e Olímpico tiveram o seu caso, sem culpa ou ressentimentos. Glória, convicta da sua vitória amorosa, sugere que Macabéa busque ajuda numa cartomante.

Domingas continuou invisível, em sua condição de mulher, no seu quartinho dos fundos, entre os silêncios, desejos e lembranças, vindo a falecer com o sentimento de amor não correspondido. Domingas parece ter sido duas vezes traída pela maternidade. A 
primeira, quando se tornou mãe postiça dos filhos da patroa e, a segunda, por ocasião do nascimento de seu filho, Nael, sendo resignada, em ambas as situações, ao cuidado dos outros, à cultura do essencialismo feminino. Não é à toa que a ideologia sempre apela para a maternidade para justificar a redução da mulher ao lugar privado do lar, pois ser mãe é quase que ser uma santa e nunca uma mulher de desejo. Não aguentando mais tanta dor e desejo sufocados, Domingas, mulher que passou sem ser notada, despede-se da vida:

Era quase meio-dia, e minha mãe não estava na cozinha. Eu a encontrei enrolada na rede de Omar, que ela armara em seu quartinho. A rede perdera a cor original e o vermelho, sem vibração, tornarase apenas um hábito antigo do olhar. Vi os lábios dela ressequidos, o olho direito fechado, o outro coberto por uma mecha grisalha. Afastei a mecha, vi o outro olho fechado. Balancei a rede, minha mãe não se mexeu. Ela não dormia. Vi o corpo que oscilava lentamente, comecei a chorar. Sentei no chão ao lado dela e fiquei ali, aturdido, sufocado. Durante o tempo que a contemplei, no vaivém da rede, rememorei as noites que dormimos juntos abraçados no mesmo quartinho que fedia a barata. (DI, p. 243)

Por outro lado, o reconhecimento da condição e dignidade de mulher que faltou à Domingas, chega, finalmente, para Macabéa, através da cartomante, uma mulher que sabe das coisas e prevê o futuro, que se diz "protegida por Jesus", de quem é "fâ" e "doidinha por ele", mas que é "perseguida pela polícia" (HE, p. 73). Apesar do humor da cena Macabéa consegue se reconhecer como mulher interessante e com direito a um futuro porque as palavras que saíram da boca da profetisa tinham o poder de alterar a vida de qualquer pessoa porque as cartas não mentem. Macabéa saiu renovada e revigorada, de corpo e alma leves, outra pessoa. Só não contava que a sua hora fosse chegar tão depressa e que a sua estrela fosse brilhar justamente nos para-choques de um carro: "E enorme como um transatlântico o Mercedes amarelo pegou-a - e neste mesmo instante em algum único lugar do mundo um cavalo como resposta empinou-se em gargalhada de relincho.” (HE, p. 79).

Desta forma, podemos perceber que as consequências da invisibilidade social, da exploração, da rejeição e da assimetria nas vidas das personagens Macabéa e Domingas, têm relação direta com os processos de desenraizamento, pelo apagamento dos vínculos 
sociais e memórias e de despersonalização, pela castração do desejo e silenciamento. Bosi (2006) afirma que o aniquilamento dos vínculos sociais é uma condição desagregadora:

Ter um passado, eis outro direito da pessoa que deriva de seu enraizamento. Entre as famílias mais pobres a mobilidade extrema impede a sedimentação do passado, perde-se a crônica da família e do indivíduo em seu percurso errante. Eis um dos mais cruéis exercícios da opressão econômica sobre o sujeito: a especulação das lembranças. (BOSI, 2006, p. 443)

O que tanto Clarice Lispector quanto Milton Hatoum postulam é a possibilidade de releitura de velhos problemas da sociedade, um olhar sobre o atraso da ideologia dominante e a necessidade de superação da prática de subordinação e de violência contra a mulher. Segundo Stuart Mill (2006), a inferiorização da mulher é um dos maiores impedimentos para o desenvolvimento humano. Por isso, a opção por uma mulher nordestina e semianalfabeta, de um lado, e de uma mulher indígena, de outro, representantes de lugares socialmente marginalizados, pode configurar-se como um pedido de empatia para com a singularidade do outro, "porque se houver algum leitor para essa história quero que ele se embeba da jovem assim como um pano de chão todo encharcado" (HE, p. 39). As mulheres das nossas histórias foram vistas apenas em função da tarefa que desempenhavam, em posição assimétrica, representando, nos termos de Perrot (2007, p. 118), um "Símbolo [...] de um desprezo intolerável...”, construído socialmente. Para Macabéa e Domingas foi negada a possibilidade de interação, de amizade, de amor, de companheirismo, de reconhecimento e de bem-estar, e suas origens e classes sociais foram decisivas no processo de ruína, restando-lhes apenas uma travessia arruinada entre a dor e a violência. Suas vozes ecoam em nossos ouvidos, imensas, inquietando-nos para o movimento imprescindível de visibilidade, que deve ser, afinal, o nosso caminho no mundo.

\section{INVISIBLE WOMEN IN CLARICE LISPECTOR'S A HORA DA ESTRELA AND MILTON HATOUM'S DOIS IRMÃOS: MACABÉA AND DOMINGAS}

ABSTRACT: This article aims to bring together the characters Macabéa, from the novel $A$ bora da estrela (1977) by Clarice Lispector and Domingas, from the novel Dois irmãos (2000) by Milton Hatoum, in view of the emergence of the discussion about the invisibility of women as a social construction. Macabéa is a northeastern woman, poor, ugly, retreatant, semi-literate, virgin and typist, 
who migrates to Rio de Janeiro and there suffers all kinds of prejudice and violence, being outside the attributes required by the big city. Domingas is an indigenous woman, victim of various types of violence and ignored in her uniqueness. Two stories that cross time and space and that reflect Brazilian social inequality and the challenges to overcome the subordinate condition of women. Some thinkers, including Michelle Perrot (2007), Alfredo Bosi (1981), Ecléa Bosi (2006), Antônio Cândido (2011), Stuart Mill (2006), Quijano (2005), and others will help us to reflect on these issues.

KEYWORDS: Woman; Invisibility; Clarice Lispector; Milton Hatoum.

\section{REFERÊNCIAS}

ANDRADE, Maria das Graças F. Mulher é desdobrável: autores e personagens em A hora da estrela e Um sopro de vida, de Clarice Lispector. In: V Seminário Internacional $M u$ lher e Literatura, 2011, Brasília. Anais XIV Seminário Nacional Mulher e Literatura, v. 1, n. 01, 2011. p. 1729-1740. Disponível em: http://docplayer.com.br/7360156-Mulher-e-desdobravel-autores-e-personagens-em-a-hora-da-estrela-e-um-sopro-de-vida-de-clarice-lispector.html

BARROS, Manoel. Ensaios fotográficos. Rio de Janeiro: Record, 2000.

BAKHTIN, M. Estética da criação verbal. Trad. Maria Emsantina Galvão G. Pereira 2. ed. São Paulo Martins Fontes, 1997, p. 26-27.

BOSI, Alfredo. A máscara e a fenda. Machado de Assis: Coleção Escritores Brasileiros. São Paulo: Ática, 1981, p. 20.

BOSI, Ecléa. Memória e Sociedade: lembranças de velhos. 13. ed. São Paulo: Companhia das Letras, 2006.

BRANCO, Lúcia Castello. O que é escrita feminina. São Paulo: Brasiliense, 1991.

CÂNDIDO, Antônio. O direito a literatura. In: Vários Escritos. 5. ed. Rio de Janeiro: Ouro sobre Azul/ São Paulo: Duas Cidades, 2011, p. 178.

HATOUM, Milton. Dois irmãos. São Paulo: Companhia das Letras, 2000.

. Flaubert, Manaus e madame Liberalina. Synergies Brésil n 7 - 2009 p. 87-89.

HOLANDA, Sérgio Buarque. Raízes do Brasil. 26. ed. São Paulo: Companhia das Letras, 2002.

HOUAISS, Antônio. Dicionário Houaiss da Lingua Portuguesa. Rio de Janeiro: Ed. Objetiva, 2001.

KOPENAWA, D. \& ALBET, B. A queda do céu: palavras de um xamã yanomami. Trad. Beatriz Perrone-Moisés. São Paulo: Companhia das Letras, 2015.

LERNER, J. Clarice Lispector, essa desconbecida... São Paulo: Via Lettera, 2007. 
LISPECTOR, Clarice. A hora da estrela. Rio de Janeiro: Rocco, 1998. . Laços de Família. 23. ed. Rio de Janeiro: Francisco Alves, 1990. . Para não esquecer. Rio de Janeiro: Rocco, 1999.

MARICATO, Hermínia. Urbanismo na periferia do mundo globalizado: metrópoles brasileiras. São Paulo em Perspectiva, 2000.

Disponível em: https://www.scielo.br/pdf/spp/v14n4/9749.pdf

MEDEIROS, Lígia Regina Calado de. Macabéa: a fabulação como direito ao grito: ANTARES, v. 9, n. 18, jul/dez 2017. Disponível em: http://www.ucs.br/etc/revistas/index.php/antares/article/viewFile/5535/3148

MELLO, Lucius de. Dois irmãos e seus precursores: o mito e a bíblia na obra de Milton Hatoum. São Paulo: Humanitas: Fapesp, 2014.

MILL, John Stuart. A Sujeição das Mulheres. Trad. Debóra Ginza. Editora Escala, São Paulo, 2006.

PERROT, Michelle. Minha história das mulheres. Trad. Ângela M. S. Côrrea. São Paulo: Contexto, 2007.

QUIJANO, Aníbal. Colonialidade do poder, eurocentrismo e América Latina. In: LANDER, Edgardo (Org.). A colonialidade do saber: Eurocentrismo e ciências sociais. Perspectivas latino-americanas. Buenos Aires: CLACSO, 2005.

RIBEIRO, D. O povo brasileiro: A formação e o sentido do Brasil. 2. ed.. São Paulo: Companhia das Letras, 1996.

SANTOS, B. S.; MENESES, M. P. (Org.). Epistemologias do Sul. São Paulo: Cortez, 2009.

SCHWARZ, Roberto. Ao vencedor as batatas. São Paulo: Duas cidades, 1988.

Recebido em: 30/09/2020.

Aprovado em: 30/12/2020. 